\title{
Pharmacological applications of azido complexes derived from N-(2'-hydroxyacetophenone)-L-alanate
}

\author{
J. Saranya ${ }^{1}$ and Sundaramurthy Santha Lakshmi* \\ ${ }^{1,}$ Research Scholar, PG and Research Department of Chemistry, D.K.M College for Women \\ (Autonomous), Vellore-632001. \\ *Assistant Professor, PG and Research Department of Chemistry, D.K.M College for Women \\ (Autonomous), Vellore-632001. \\ (*Corresponding author E-mail: santhalakshmi76@gmail.com)
}

\begin{abstract}
L-alanineis a non-essential amino acid, but it is an essential source of energy for the central nervous system and strengthens the immune system. Considering the significances of amino acid based Schiff base complexes, four new azido complexes of Co(II), Ni(II), Cu(II) and $\mathrm{Zn}(I I)$ of Schiff base ligand N-(2'-hydroxyacetophenone)-L-alanate has been designed and synthesized. These compounds were characterized on the basis of molar conductance, $U V$-Visible, FTIR, ${ }^{1} H$ NMR, ${ }^{13} \mathrm{C} N M R$ and EPR spectra. FTIR spectra confirmed the tridentate coordination nature of the Schiff base. The structure of the synthesized Schiff base was confirmed by ${ }^{1} H$ NMR and ${ }^{13} C N M R$. Antibacterial and antifungal activities were carried out against four pathogenic microorganisms namely Staphylococcus aureus, Escherichia coli, Pseudomonas aeruginosa, Bascillus subtilis, Aspergillus flavus, Candida albicans, Rhizhopus stolonifer, Aspergillus niger by well diffusion method. Radical scavenging activity was carried out by DPPH, $\mathrm{H}_{2} \mathrm{O}_{2}, \mathrm{CUPRAC}$ and FRAP methods. Mosquito larvicidal and ovicidal activities against Culex quinquefasciatus larvae over $24 \mathrm{~h}$ exposure time were performed for the synthesized compounds. Further, $L C_{50}$ and $L C_{90}$ values were calculated.
\end{abstract}

Keywords: Schiff base ligand, azido complexes, antifungal, antibacterial, Culex quinquefasciatus

\section{Introduction}

In modern years, bacterial resistance to antibiotics has been a proposal of great concern due to emerging infectious diseases [1]. Metal complexes possess vital role in pharmaceutical industries especially transition metals based Schiff base complexes are used in several aspects because of their antimicrobial, antioxidant, antitumour, anti-inflammatory, wound healing and larvicidal properties [2,3]. The management of communicable diseases still remains a taxing problem because of budding transmittable diseases and the mounting number of multidrug resistant microbes. Therefore, existing drugs are inadequate. Hence there is a need to find some new drug for the treatment of new pathogenic microbes infectious diseases $[4,5]$.

Schiff bases are versatile organic blockers which can readily combine with metal ions of diverse oxidation states to form promising metal complexes [6,7]. Biological activity of the metal complexes has been improved when it is coordinate with potent ligand such as Schiff base. The existence of imine moiety into the structure of the coordinated complexes often 
resulted in essential changes in their behavior towards metal ions. Many researchers focus on their research in interdisciplinary field to produce better results in pharmacological activities which are essential nowadays [10]. Until now, azide and L-alanine based Schiff base first row transition metal (II) compounds were not yet reported. However, antibacterial activity of mixed ligand using azide as co-ligand was reported [11]. The superior anticancer, antioxidant and antimicrobial activities were found in amino acid based Schiff base transition metal complexes [13]. In this regard, we made an attempt to synthesize imine based metal (II) complexes using azide as coligand and to investigate their pharmacological activities.

\section{Materials and Methods}

Analytical grade of chemicals were used for the synthesis of the compounds. Schiff base ligand and their complexes were prepared and handled with care since azido based complexes are explosive. Culex quinquefasciatus larvae were received from Zonal Entomological Unit, Vellore, Tamil Nadu. The UV-Visible spectra of the compounds were recorded on a SYSTRONICS 2201 spectrophotometer at room temperature with the sample concentration of $10^{-5} \mathrm{M}$ in DMSO. The FITR spectra were recorded on SHIMADZU spectrophotometer between $4000-400 \mathrm{~cm}^{-1}$ range, using $\mathrm{KBr}$ pellet. The EPR spectra were recorded in solid state at room temperature using Bruker EMX -10/2.7 spectrometer. ${ }^{1} \mathrm{H}$ and ${ }^{13} \mathrm{C}$ NMR spectra of Schiff base ligand were run on a Bruker Advance $300 \mathrm{MHz}$ instrument using DMSO solvent.

\subsection{Synthesis of Schiff base ligand $\left(\mathrm{L}^{1}=\mathrm{N}-\left(2^{\prime}\right.\right.$-hydroxyacetophenone $)-\mathrm{L}$-alanate $)$}

Ligand was synthesized by adding an aqueous solution of L-alanine $(0.267 \mathrm{~g}, 3 \mathrm{mmol})$ and potassium hydroxide $(0.336 \mathrm{~g}, 6 \mathrm{mmol})$ to an ethanolic solution of $(25 \mathrm{~mL})$ of o-hydroxyacetophenone $(0.45 \mathrm{~mL}, 3 \mathrm{mmol})$ and the reaction was continued with constant stirring at $333 \mathrm{~K}$ for $2 \mathrm{~h}$ using a magnetic stirrer. The solution turned pale yellow to orange yellow. The total volume of the solution is reduced to get concentrated product. The formation of Schiff base was confirmed by TLC.

\subsection{Synthesis of metal azido Schiff base complexes}

Metal azido complexes were synthesized by adding acetate salts of metals to the synthesized ligands. To the hot ethanolic solution of ligand $\left(\mathrm{L}^{1}\right)$,copper (II) acetate monohydrate $(0.597 \mathrm{~g}, 3 \mathrm{mmol})$ was added. This mixture was allowed to stir for $2 \mathrm{~h}$ at $333 \mathrm{~K}$. Further, sodium azide $(0.195 \mathrm{~g}, 3 \mathrm{mmol})$ in methanol / water (1:9) mixture was freshly prepared and added in drops to the above mixture on continuous stirring and the process was persistent for another $2 \mathrm{~h}$ at the same temperature. The resultant turbid green solution was filtered and kept at room temperature to evaporate the solvent. Final product was formed on slow evaporation of the mother liquor at room temperature.

The procedure mentioned above was carried out for the preparation other complexes using nickel (II) acetate tetrahydrate $(3 \mathrm{mmol})$, cobalt (II) acetate tetrahydrate $(3 \mathrm{mmol})$ and zinc(II) acetate dehydrate $(3 \mathrm{mmol})$. 


\section{Results and Discussion}

\subsection{Analytical data of the synthesized compounds}

$\mathrm{L}^{1}$ : (N-(2'-hydroxyacetophenone)-L-alanate): Brown solid; MW: 207.23; MF: $\mathrm{C}_{11} \mathrm{H}_{13} \mathrm{NO}_{3}$; M.p.(decomp. T): $250^{\circ} \mathrm{C}$. Complex 1: dark brown semicrystalline solid; MF: $\mathrm{C}_{11} \mathrm{H}_{11} \mathrm{~N}_{4} \mathrm{CoNaO}_{3}$; MW: 315.15; M.p.(decomp. T): $300^{\circ} \mathrm{C} ; \Lambda_{\mathrm{M}}(\mathrm{DMF})=51.33 \mathrm{~cm}^{2} \Omega^{-1} \mathrm{M}^{-1}$. Complex 2: dark green precipitate; MF: $\mathrm{C}_{11} \mathrm{H}_{11} \mathrm{~N}_{4} \mathrm{NiNaO}_{3}$; $\mathrm{MW}$ : 328.91; melting point = M.p.(decomp. T): $280^{\circ} \mathrm{C} ; \Lambda_{\mathrm{M}}(\mathrm{DMF})=53.27 \mathrm{~cm}^{2} \Omega^{-1} \mathrm{M}^{-1}$. Complex 3: dark green crystalline solid; MF: $\mathrm{C}_{11} \mathrm{H}_{11} \mathrm{~N}_{4} \mathrm{CuNaO}_{3}$; MW: 333.77; M.p.(decomp. T): $>300^{\circ} \mathrm{C} ; \Lambda_{\mathrm{M}}(\mathrm{DMF})=63.32$ $\mathrm{cm}^{2} \Omega^{-1} \mathrm{M}^{-1}$. Complex 4: dark yellowish brown precipitate; MF: $\mathrm{C}_{11} \mathrm{H}_{11} \mathrm{~N}_{4} \mathrm{ZnNaO}_{3}$; $\mathrm{MW}$ : 335.63; M.p. (decomp.T): $>300^{\circ} \mathrm{C} ; \Lambda_{\mathrm{M}}(\mathrm{DMF})=52.22 \mathrm{~cm}^{2} \Omega^{-1} \mathrm{M}^{-1}$.

[where,Complex $\mathbf{1}=\mathrm{Na}\left[\mathrm{CoL}^{1} \mathrm{~N}_{3}\right]$, Complex $\mathbf{2}=\mathrm{Na}\left[\mathrm{NiL}^{1} \mathrm{~N}_{3}\right]$, Complex $\mathbf{3}=\mathrm{Na}\left[\mathrm{CuL}^{1} \mathrm{~N}_{3}\right]$, Complex $4=\mathrm{Na}\left[\mathrm{ZnL}^{1} \mathrm{~N}_{3}\right]$.

The synthesized Schiff base complexes $\left(10^{-3} \mathrm{M}\right)$ are found to be $1: 1$ electrolytes since the molar conductance value of the complexes fall in the range $58-80 \mathrm{~cm}^{2} \Omega^{-1} \mathrm{M}^{-1}$ in DMF [13].

\subsection{UV-Visible spectra}

The formation of the imine moiety $\left(>\mathrm{C}=\mathrm{N}\right.$ ) linkage present in $\mathrm{L}^{1}$ can be confirmed by the absorption maximum appeared at $260 \mathrm{~nm}$ and $310 \mathrm{~nm}$ are due to $\pi \rightarrow \pi^{*}$ and $\mathrm{n} \rightarrow \pi^{*}$ transitions respectively. Intraligand $\pi \rightarrow \pi^{*}$ transitions of the synthesized complexes were confirmed by the absorption maximum appeared around 220 to $280 \mathrm{~nm}$. LMCT showed bands at high energy from 350-380 nm [14]. Except complex 4, all other synthesized complexes exhibit broad band in the region of 660-700 nm which confirms that these complexes possess $d \rightarrow d$ transitions due to presence of the unpaired electrons [15], whereas, this transitions was not observed for the $\mathrm{Zn}$ (II) complex (Complex 4) due to lack of unpaired electrons.

Table 1: UV-Visible spectral data of the synthesized compounds

\begin{tabular}{|l|c|c|c|}
\hline \multirow{2}{*}{ Compound } & \multicolumn{3}{|c|}{ Absorption $(\lambda \max \mathrm{nm})$} \\
\cline { 2 - 4 } & $\pi-\pi^{*}$ & $\mathrm{n}-\pi^{*}$ & $\mathrm{~d}-\mathrm{d}$ \\
\hline $\mathrm{L}^{1}$ & 260 & 310 & Nil \\
\hline Complex 1 & 260 & 380 & 700 \\
\hline Complex 2 & 220 & 350 & 700 \\
\hline Complex 3 & 260 & 350 & 660 \\
\hline Complex 4 & 280 & 380 & Nil \\
\hline
\end{tabular}

\subsection{FTIR spectra}

FTIR absorption band appeared around $1587 \mathrm{~cm}^{-1}$ confirms the formation of imine linkage in the ligand. This absorption band is shifted to lower and higher stretching value in the complexes may be the coordination towards metal ions. The variation between asymmetric and symmetric stretching value of the carboxylate in the Schiff base transition metal complexes were resulted to be higher than the resultant free carboxylate anion 
$\left(192 \mathrm{~cm}^{-1}\right)$ which says that the monodentate coordination of the carboxylate anion in the synthesized complexes [16].

The bands appeared around 400 to $490 \mathrm{~cm}^{-1}$ are assigned to the formation of $\mathrm{M}-\mathrm{O}$ and 500 to $545 \mathrm{~cm}^{-1}$ are due to the structure of M-N bonding [17]. The FTIR spectra confirmed the tridentate coordination nature of the Schiff base via imine nitrogen, phenolic oxygen atom and one of the oxygen atom of the carboxylate group. Hence, the Schiff base ligand is tridentate. Further, the IR spectra of the complexes also exhibit peaks in the region of $1352-1384 \mathrm{~cm}^{-1}$ and $650-690 \mathrm{~cm}^{-1}$ corresponding to symmetric stretching and bending mode of azidemoiety $\delta\left(\mathrm{N}_{3}\right)$. One sharp and strong peak appeared at 2135 to $2150 \mathrm{~cm}^{-1}$ in the complexes indicates the presence of one of the nitrogen atom of an azide bonded to the metal ion $[18,19]$.

\subsection{EPR spectrumof Complex 3}

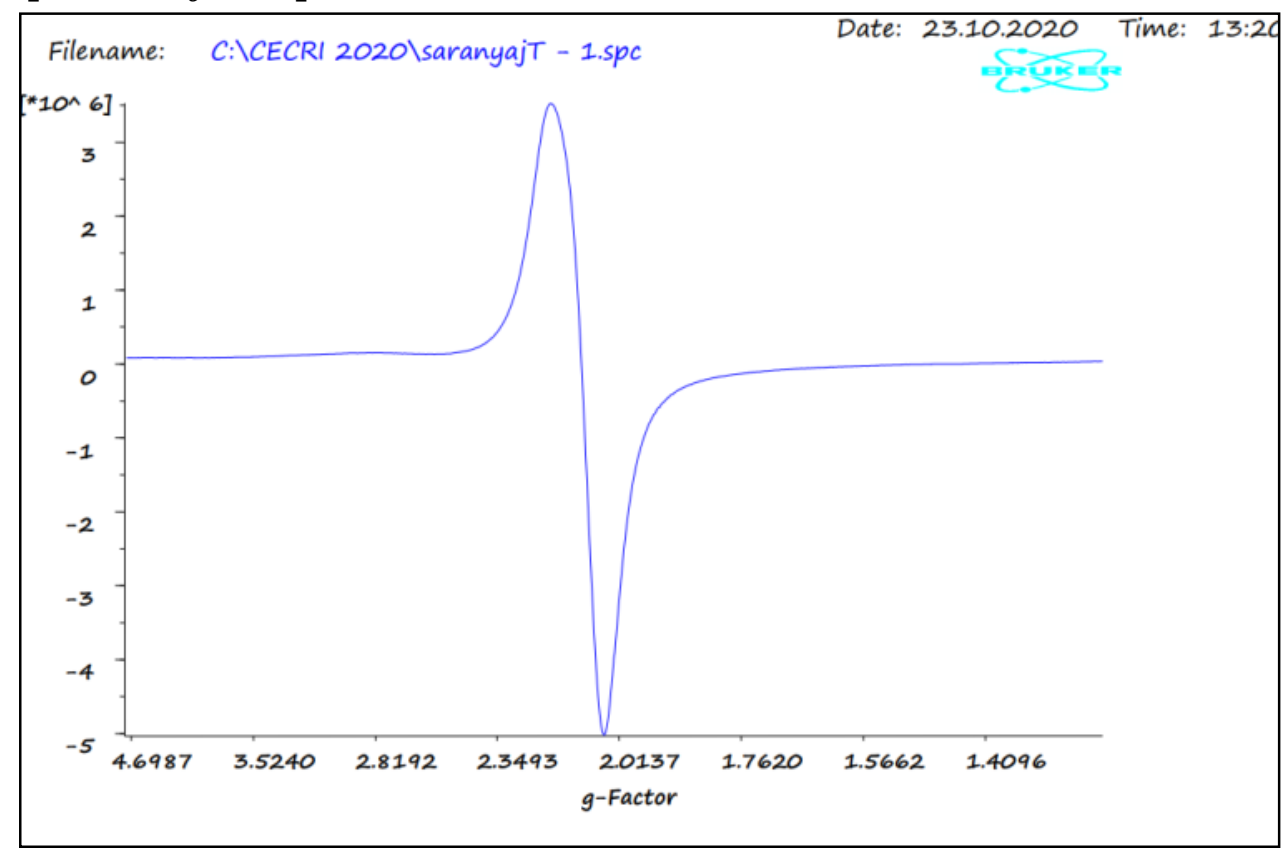

Figure 1. EPR spectrum of Complex 3

The paramagnetic behavior of the polycrystalline Complex 3 (copper(II) complex) shows an isotropic peak with $g_{i s o}$ values at 2.0137. This $g_{\text {iso }}$ value evident that with respect to axial symmetry all the principal axes aligned parallel. This behavior can suggest symmetrical environment around metal ions and expected for square planar, octahedral and square pyramidal geometry of the Complex 3 [20].

\section{$3 .{ }^{1} \mathrm{H}$ NMR Spectrum}

The ${ }^{1} \mathrm{H}$ NMR spectrum(Figure 2)of the N-(2'-hydroxyacetophenone)-L-alanatevalues are assigned as follows. 


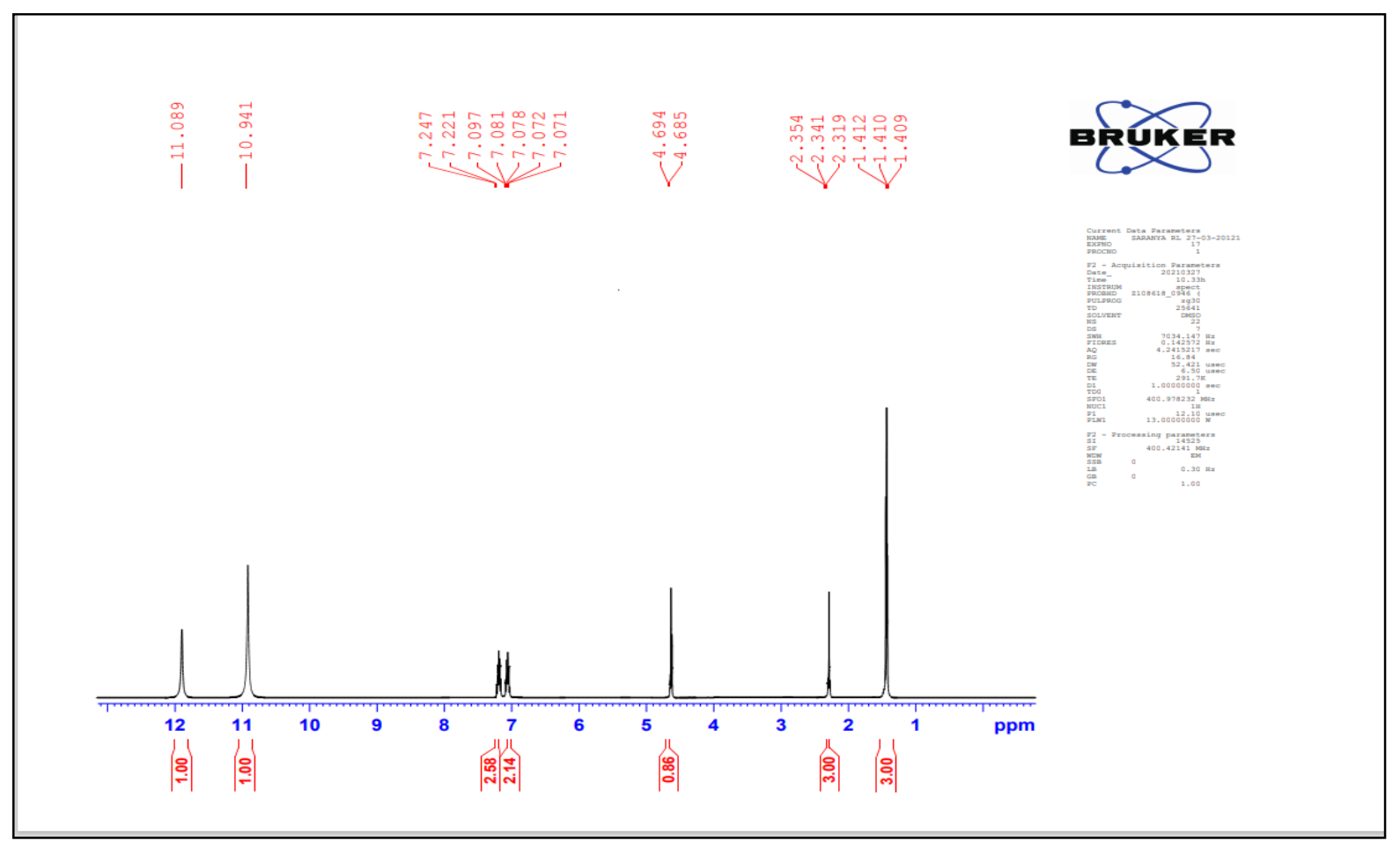

Figure 2. ${ }^{1} \mathrm{H}$ NMR Spectrum of the Schiff base ligand $\left(L^{1}\right)$

Table 2. ${ }^{1} \mathrm{H}$ NMR Spectral data of the Schiff base ligand

\begin{tabular}{|l|l|}
\hline Functional Group & $\delta(\mathrm{ppm})$ \\
\hline Azomethine methyl proton $\left(-\mathrm{CH}_{3}-\mathrm{C}=\mathrm{N}\right)$ & $2.3(3 \mathrm{H}, \mathrm{s})$ \\
\hline Aromatic hydroxyl proton (Ar-O-H) & $11.0(\mathrm{~s})$ \\
\hline Aromatic protons (Ar-C-H protons) & $7.2-7.07(\mathrm{~m})$ \\
\hline Aliphatic protons of L-alanine $\left(-\mathrm{CH}_{3}\right)$ & $1.4(3 \mathrm{H}, \mathrm{d}, \mathrm{J}=7.1 \mathrm{~Hz})$ \\
\hline Saturated C-H proton of L-alanine & $4.6(1 \mathrm{H}, \mathrm{q}, \mathrm{J}=7.1 \mathrm{~Hz})$ \\
\hline Aliphatic hydroxyl proton of L-alanine & $10.09(1 \mathrm{H}, \mathrm{s})$ \\
\hline
\end{tabular}

The signal at $\delta=1.4(3 \mathrm{H}, \mathrm{d}, \mathrm{J}=7.1 \mathrm{~Hz})$ is attributed to aliphatic $\left(-\mathrm{CH}_{3}\right)$ protons of L-alanine. The signal of azomethine methyl proton was seen at $\delta=2.3(3 \mathrm{H}, \mathrm{s})$. The signal of aliphatic hydroxyl proton was observed at $10.09(1 \mathrm{H}, \mathrm{s})$. The signal at $\delta=7.2-7.07(\mathrm{~m})$ corresponds to aromatic protons [21, 22]. 


\section{6 $\quad{ }^{13}$ C NMR Spectrum}

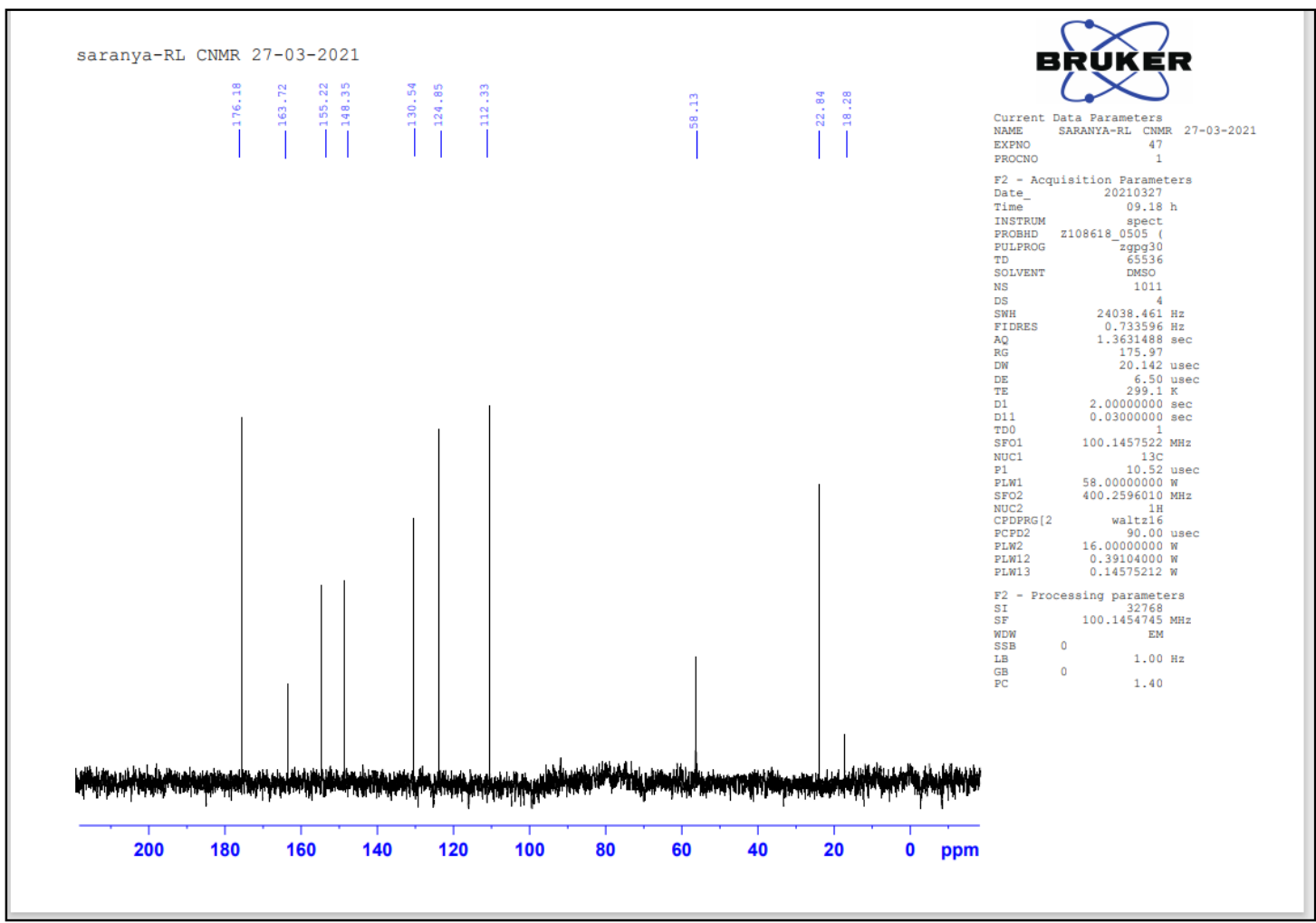

Figure $3 .{ }^{13} \mathrm{C}$ NMR Spectrum of the Schiff base ligand $\left(\mathrm{L}^{1}\right)$

Table 3. ${ }^{13} \mathrm{C}$ NMR Spectral data of the Schiff base ligand $\left(\mathrm{L}^{\mathbf{1}}\right)$

\begin{tabular}{|l|l|}
\hline Functional Group & $\delta(\mathrm{ppm})$ \\
\hline Azomethine carbon $\left(-\mathrm{CH}_{3}-\mathrm{C}=\mathrm{N}\right)$ & $155(\mathrm{~S})$ \\
\hline Aromatic hydroxyl carbon $(\mathrm{C}-\mathrm{OH})$ present in & $148(\mathrm{~S})$ \\
\hline Aliphatic carbon $(\mathrm{C}=\mathrm{O})$ present in L-alanine & $176(\mathrm{~S})$ \\
\hline Aliphatic saturated carbon $\left(-\mathrm{CH}_{3}\right)$ & $19(\mathrm{~S}), 22(\mathrm{~S})$ \\
\hline
\end{tabular}

The ${ }^{13} \mathrm{C}$ NMR spectra of Schiff base ligand (Figure 3) showed a singlet at $155 \mathrm{ppm}$, due to azomethine carbon atom. The $(\mathrm{C}=\mathrm{O})$ and $(\mathrm{C}-\mathrm{OH})$ carbons of the Schiff base ligand were observed at 176 and $148 \mathrm{ppm}$ respectively. The saturated carbon of $\left(-\mathrm{CH}_{3}\right.$ group) exhibited a signal at $19 \mathrm{ppm}$ and $22 \mathrm{ppm}$. The peak appeared at $130 \mathrm{ppm}, 124 \mathrm{ppm}$ and 112 $\mathrm{ppm}$ are due to aromatic carbon atom of $(\mathrm{C}=\mathrm{C})$ groups [22]. In addition, this study supports to the binding mode of their FTIR and ${ }^{1} \mathrm{H}$ NMR of synthesized Schiff base ligand.

\subsection{Larvicidal and Ovicidal activities}

The standard method of WHO was followed with slender modifications [23]. The fourth stage larvae and early stage eggs of Culex quinquefasciatus were maintained in the laboratory [23]. Preliminary analysis was carried out by taking $2 \mathrm{mg}$ of the synthesized compounds and mortality was noted. The movements of the larvae were observed for $24 \mathrm{~h}$ exposure time. Percentage of mortality was calculated as per the standard method [24]. Statistical analyses are represented as Mean \pm Standard Deviation (SD) values. Sterilized distilled water without 
synthesized complexes was taken as control which exhibits zero mortality. Percentages of mortality for larvicidal and ovicidal analysis were performed and the data are given in Tables 4 and 5.

Table 4. Larvicidal activity data of the synthesized compounds

\begin{tabular}{|c|c|c|c|c|c|c|c|c|}
\hline \multirow[t]{2}{*}{ Compound } & \multicolumn{4}{|c|}{ Concentration / \% Mortality \pm SD } & \multirow{2}{*}{$\begin{array}{c}\mathrm{LC}_{50} \\
\mathrm{mg} / 100 \\
\mathrm{~mL}\end{array}$} & \multirow{2}{*}{$\begin{array}{c}\mathrm{LC}_{90} \\
\mathrm{mg} / 100 \\
\mathrm{~mL}\end{array}$} & \multirow[t]{2}{*}{$\chi^{2}$} & \multirow[t]{2}{*}{ df } \\
\hline & $\begin{array}{l}4 \mathrm{mg} \\
/ 100 \\
\mathrm{~mL}\end{array}$ & $\begin{array}{l}2 \mathrm{mg} \\
/ 100 \\
\mathrm{~mL}\end{array}$ & $\begin{array}{l}1 \mathrm{mg} \\
/ 100 \\
\mathrm{~mL}\end{array}$ & $\begin{array}{l}0.5 \mathrm{mg} \\
/ 100 \\
\mathrm{~mL}\end{array}$ & & & & \\
\hline $\mathrm{L}^{1}$ & $10 \pm 8.56$ & $5 \pm 9.82$ & - & - & - & - & - & \multirow[t]{4}{*}{3} \\
\hline Complex 1 & $45 \pm 0.46$ & $40 \pm 5.92$ & $30 \pm 0.34$ & $15 \pm 6.10$ & 4.22 & 9.57 & 4.84 & \\
\hline Complex 2 & $75 \pm 0.35$ & $70 \pm 5.46$ & $50 \pm 0.48$ & $45 \pm 0.9$ & 7.25 & 5.32 & 5.3 & \\
\hline Complex 3 & $85 \pm 0.36$ & $75 \pm 0.67$ & $50 \pm 0.12$ & $45 \pm 0.10$ & 0.70 & 4.11 & 10.16 & \\
\hline Complex 4 & $70 \pm 5.46$ & $65 \pm 0.44$ & $45 \pm 0.48$ & $30 \pm 0.34$ & 1.64 & 5.41 & 8.18 & \\
\hline
\end{tabular}

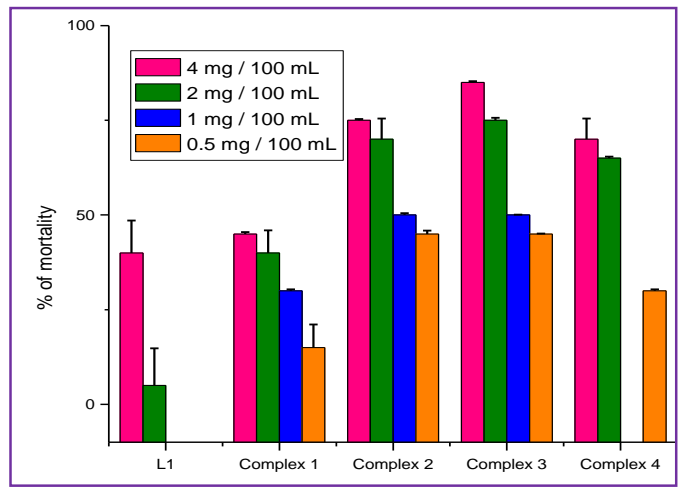

Figure 4. Graphical representation of the larvicidal activity

Table 5.Ovicidal activity data of the synthesized compounds

\begin{tabular}{|c|c|c|c|c|c|c|c|c|}
\hline \multirow[t]{2}{*}{ Compound } & \multicolumn{4}{|c|}{ Concentration / \% Mortality \pm SD } & \multirow{2}{*}{$\begin{array}{c}\mathrm{LC}_{50} \\
\mathrm{mg} / 100 \mathrm{~mL}\end{array}$} & \multirow{2}{*}{$\begin{array}{c}\mathrm{LC}_{90} \\
\mathrm{mg} / 100 \\
\mathrm{~mL}\end{array}$} & \multirow[t]{2}{*}{$\chi^{2}$} & \multirow[t]{2}{*}{ df } \\
\hline & $\begin{array}{c}4 \mathrm{mg} \\
/ 100 \\
\mathrm{~mL}\end{array}$ & $\begin{array}{c}2 \mathrm{mg} \\
/ 100 \\
\mathrm{~mL}\end{array}$ & $\begin{array}{c}1 \mathrm{mg} \\
/ 100 \\
\mathrm{~mL}\end{array}$ & $\begin{array}{c}0.5 \mathrm{mg} \\
/ 100 \\
\mathrm{~mL}\end{array}$ & & & & \\
\hline $\mathrm{L}^{1}$ & Nil & Nil & Nil & Nil & - & - & - & 3 \\
\hline Complex 1 & $25 \pm 6.69$ & $20 \pm 5.65$ & $10 \pm 7.15$ & $5 \pm 6.15$ & 8.16 & 15.35 & 5.23 & \\
\hline Complex 2 & $40 \pm 8.28$ & $20 \pm 5.65$ & $10 \pm 7.25$ & $5 \pm 7.15$ & 5.00 & 9.00 & 6.28 & \\
\hline Complex 3 & $65 \pm 5.64$ & $55 \pm 6.48$ & $45 \pm 6.38$ & $30 \pm 0.34$ & 2.01 & 9.60 & 7.29 & \\
\hline Complex 4 & $55 \pm 7.48$ & $40 \pm 6.48$ & $20 \pm 5.65$ & $10 \pm 7.35$ & 3.49 & 8.55 & 6.82 & \\
\hline
\end{tabular}




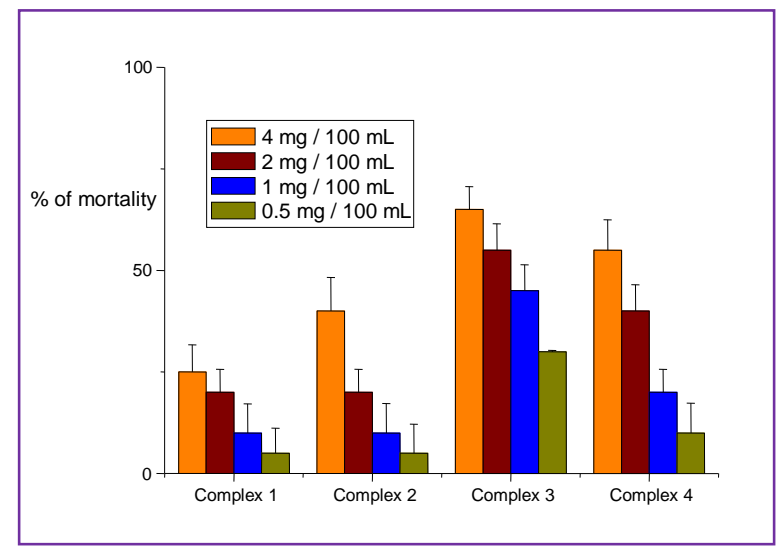

Figure 5. Graphical representation of the ovicidal activity

From the study of larvicidal and ovicidal activities against C. quinquefasciatus, it was observed that all the larvae present in control were very active and exhibited normal movement in a beaker. But in the complex solution, restless movement of the treated larvae was observed after $1 \mathrm{~h}$. This movement of the larvae decreased gradually with respect to time. The movement of the larvae was noted for $24 \mathrm{~h}$ with respect to time intervals. Finally, tremor was noted and dead larvae settle down at the bottom of the beaker. Number of dead larvae was counted and the percentage of mortality was calculated. Synthesized Schiff base ligands exhibits low mortality when compared to the complexes, hence the metal ions present in a complex plays a major role for the killing of the larvae. $\mathrm{LC}_{50}$ and $\mathrm{LC}_{90}$ and significant chi-square values are also observed. Among the synthesized complexes, the copper (II) complexes exhibits better activity against $C$. quinquefasciatus.

Due to 1:1 electrolytic nature, the complex gets ionized in water. These ions get into the larvae and hence inhibit the enzymes functions and cause the cell death. So, the nature of the metal in the complex plays an effective role in killing the larvae. As the concentration of the compounds increases percentage of mortality also increases. This was confirmed by dose response study and the results are shown in Figure 4.

In the case of ovicidal activity (Figure 5), eggs of $C$. quinquefasciatus exhibits more tolerant in ligand than in complexes. But it was quite opposite in control where hatchability of eggs was normal and percentage of mortality decreases in control than complexes.

\subsection{Antimicrobial studies}

The antimicrobial efficiency of the synthesized complexes was performed according to National Committee for Clinical Laboratory Standards [25]. Four pathogenic microorganism namely Staphylococcus aureus, Escherichia coli, Pseudomonas aeruginosa, Bascillus subtilis, Aspergillus flavus, Candida albicans, Rhizhopus stolonifer and Aspergillus niger were taken for the investigation. The stock solution was prepared with $10^{-6} \mathrm{M}$ concentration of synthesized compounds in DMSO. $50 \mu \mathrm{L}$ test solution was taken for the study. Ampicillin and Polymyxin B sulphate were taken as reference. The inhibition zones are depicted in Figures 6 and 7. Inhibition of microorganism using the lowest concentration 
of synthesized compounds is calculated (Tables 8 and 9) via test tube dilution method by standard procedure [25]. Stock solutions were prepared by using synthesized compounds $(1 \mathrm{mg} / 1 \mathrm{~mL})$ solvent and are serially diluted.

Table 6. Antibacterial activities of the synthesized compounds

\begin{tabular}{|l|l|l|l|l|}
\hline \multirow{2}{*}{ Compound } & \multicolumn{4}{c|}{ Zone of inhibition (mm) } \\
\cline { 2 - 5 } & \multicolumn{3}{|c|}{ Gram-positive } & \multicolumn{2}{c|}{ Gram-negative } \\
\cline { 2 - 5 } & $\begin{array}{c}\text { Staphylococcus } \\
\text { aureus }\end{array}$ & $\begin{array}{c}\text { Pseudomonas } \\
\text { aeruginosa }\end{array}$ & $\begin{array}{c}\text { Bascillus } \\
\text { subtilis }\end{array}$ & Escherichia coli \\
\hline $\mathrm{L}^{1}$ & $5 \pm 0.5$ & $5 \pm 0.5$ & $8 \pm 0.8$ & $8 \pm 0.8$ \\
\hline Complex 1 & $15 \pm 0.9$ & $12 \pm 1.2$ & $11 \pm 1.8$ & $11 \pm 1.9$ \\
\hline Complex 2 & $19 \pm 0.5$ & $17 \pm 1.2$ & $12 \pm 0.9$ & $12 \pm 1.5$ \\
\hline Complex 3 & $20 \pm 0.7$ & $16 \pm 1.3$ & $13 \pm 0.5$ & $13 \pm 1.5$ \\
\hline Complex 4 & $19 \pm 1.2$ & $15 \pm 0.9$ & $12 \pm 1.2$ & $11 \pm 1.9$ \\
\hline Ampicillin & $30 \pm 0.0$ & $25 \pm 0.5$ & $11 \pm 0.5$ & $16 \pm 0.0$ \\
\hline
\end{tabular}

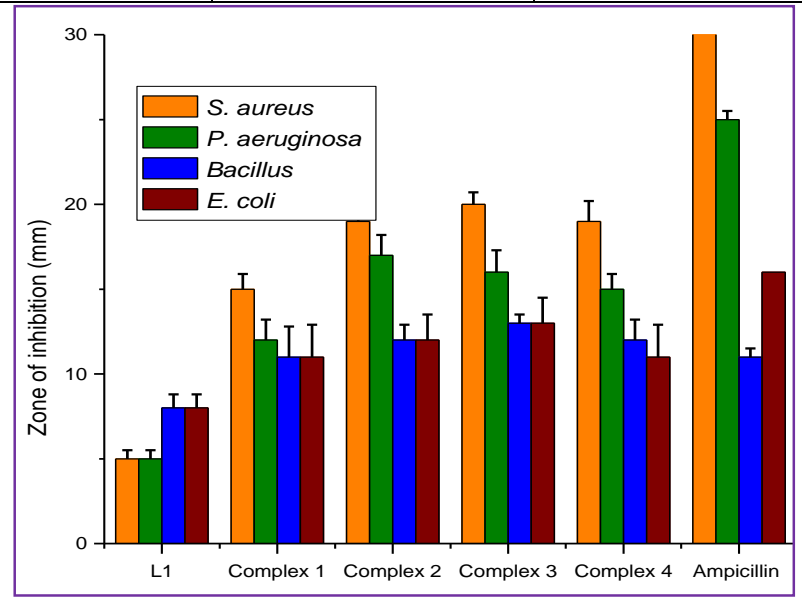

Figure 6. Zone of inhibition against bacterial strains.

Table 7. Antifungal activities of the synthesized compounds

\begin{tabular}{|l|l|l|l|l|}
\hline \multirow{2}{*}{ Compound } & \multicolumn{4}{l}{ Zone of inhibition (mm) } \\
\cline { 2 - 5 } & $\begin{array}{l}\text { Aspergillus } \\
\text { niger }\end{array}$ & $\begin{array}{l}\text { Aspergillus } \\
\text { flavus }\end{array}$ & $\begin{array}{l}\text { Candida } \\
\text { albicans }\end{array}$ & $\begin{array}{l}\text { Rhizhopus } \\
\text { stolonifer }\end{array}$ \\
\hline $\mathrm{L}^{1}$ & $6 \pm 0.5$ & $7 \pm 0.8$ & $5 \pm 0.5$ & $5 \pm 0.8$ \\
\hline Complex $\mathbf{1}$ & $11 \pm 0.8$ & $11 \pm 0.5$ & $10 \pm 1.8$ & $10 \pm 0.9$ \\
\hline Complex $\mathbf{2}$ & $11 \pm 1.5$ & $11 \pm 0.5$ & $10 \pm 0.5$ & $10 \pm 0.5$ \\
\hline Complex $\mathbf{3}$ & $16 \pm 0.9$ & $15 \pm 0.8$ & $12 \pm 0.5$ & $11 \pm 0.5$ \\
\hline Complex $\mathbf{4}$ & $14 \pm 1.5$ & $12 \pm 0.9$ & $14 \pm 1.2$ & $15 \pm 0.8$ \\
\hline $\begin{array}{l}\text { Polymyxin B } \\
\text { sulphate }\end{array}$ & $11 \pm 0.0$ & $11 \pm 0.0$ & $11 \pm 0.0$ & $11 \pm 0.0$ \\
\hline
\end{tabular}




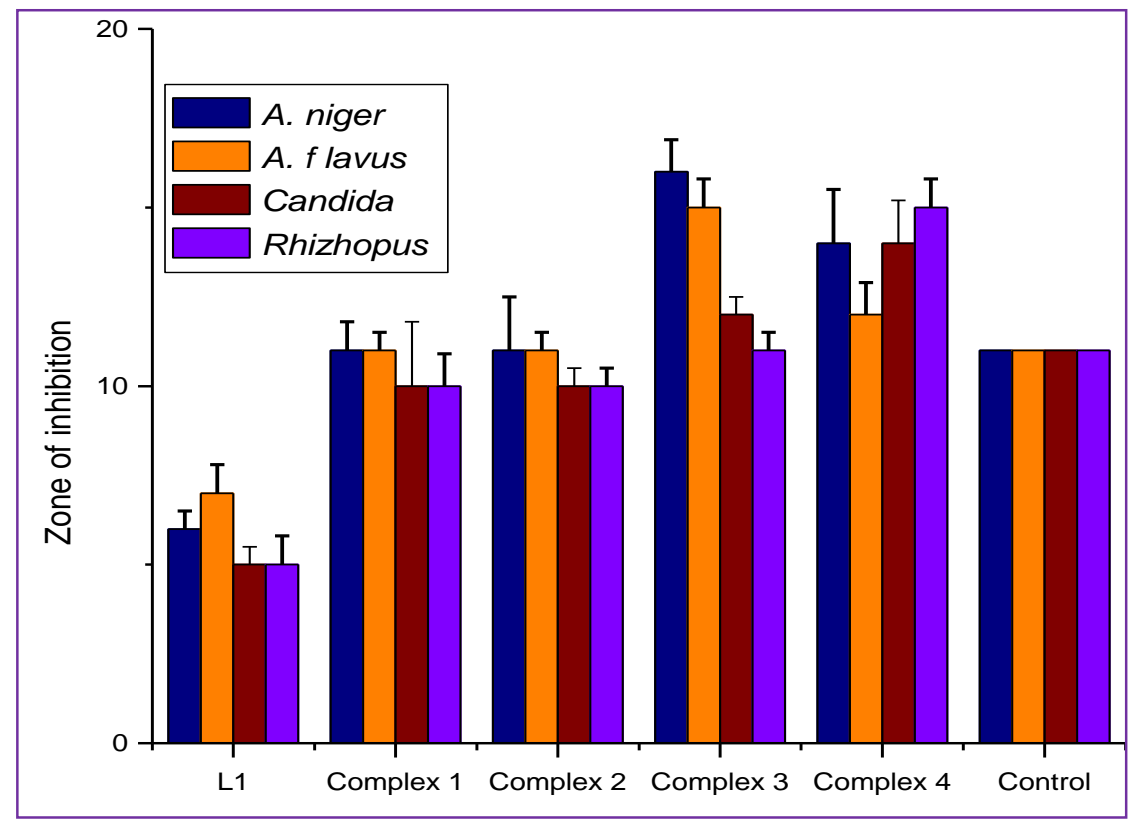

Figure 7. Zone of inhibition against fungal strains.

Table 8. MIC values against antibacterial activity $(\boldsymbol{\mu g} / \mathrm{mL}))$

\begin{tabular}{|l|c|c|c|c|}
\hline Compound & $\begin{array}{c}\text { Staphylococcus } \\
\text { aureus }\end{array}$ & $\begin{array}{c}\text { Pseudomonas. } \\
\text { aeruginosa }\end{array}$ & $\begin{array}{c}\text { Bascillus } \\
\text { subtilis }\end{array}$ & Escherichia coli \\
\hline $\mathrm{L}^{1}$ & 5 & 5 & 5 & 5 \\
\hline Complex $\mathbf{1}$ & 2.5 & 5 & 2.5 & 1.25 \\
\hline Complex $\mathbf{2}$ & 2.5 & 1.25 & 5 & 2.25 \\
\hline Complex $\mathbf{3}$ & 1.25 & 2.5 & 5 & 1.25 \\
\hline Complex $\mathbf{4}$ & 2.5 & 1.25 & 5 & 2.5 \\
\hline
\end{tabular}

Table 9. MIC values against antifungal activity $(\mu \mathrm{g} / \mathrm{mL}))$

\begin{tabular}{|l|c|c|c|c|}
\hline Compound & $\begin{array}{c}\text { Aspergillus } \\
\text { niger }\end{array}$ & $\begin{array}{c}\text { Aspergillus } \\
\text { flavus }\end{array}$ & $\begin{array}{c}\text { Candida } \\
\text { albicans }\end{array}$ & Rhizhopusstolonifer \\
\hline $\mathrm{L}^{1}$ & 10 & 10 & 5 & 5 \\
\hline Complex $\mathbf{1}$ & 2.5 & 5 & 2.5 & 1.25 \\
\hline Complex $\mathbf{2}$ & 1.25 & 1.25 & 5 & 2.25 \\
\hline Complex $\mathbf{3}$ & 2.5 & 1.25 & 1.25 & 2.5 \\
\hline Complex $\mathbf{4}$ & 2.5 & 2.5 & 5 & 2.5 \\
\hline
\end{tabular}



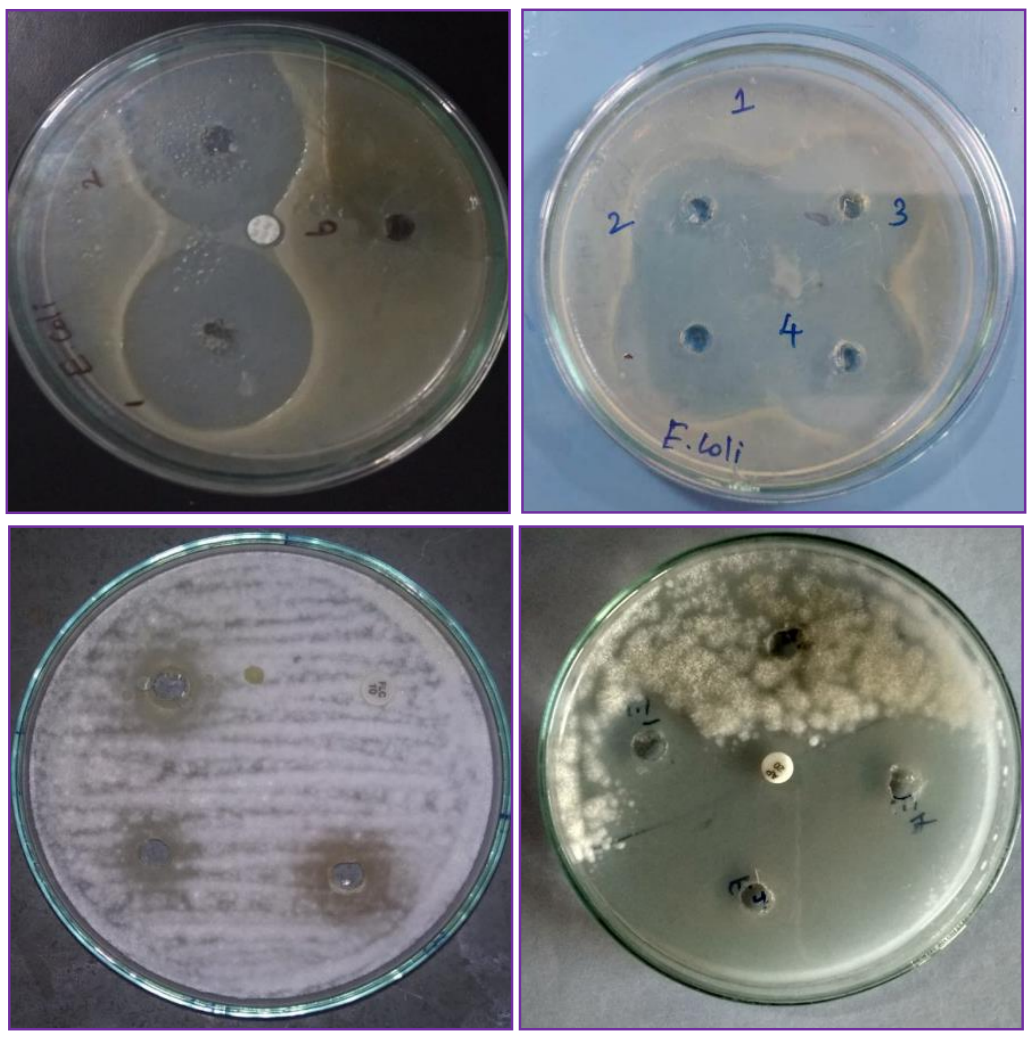

Figure 8. Images of antimicrobial activities

The inhibition zones in diameter around the well are summarized in Figures 3 and 4. It was reported that the antibacterial activity of the Schiff base ligand could be improved when the ligand is chemically or physically modified by metal ions [26]. In this work, the results also showed that moderate to stronger antibacterial behavior against gram positive and gram negative bacteria. It was noted zone of inhibition values enhanced in complexes when compared to the corresponding ligand. Complexes $\mathbf{1}$ and $\mathbf{2}$ showed moderate activity against selected bacterial stains. Complexes $\mathbf{3}$ and $\mathbf{4}$ exhibited marginally higher activity against S. aureus and Bacillus.

This superior antibacterial property may be due to release of complex ions into the bacterial cell wall this upshot in bacteria cell wall leakage. Once the complex ions get into the bacteria cell, the interaction with the enzyme prosthetic group arises that can inhibit the replication of DNA. It is interesting that the complex $\mathbf{3}$ showed relatively better antibacterial activity as compared to other complexes. This is due to effective chelating of the $\mathrm{Cu}$ (II) ion to the ligand and also the change in the structure of the compounds based on the polarity of the metals.

It is also evident that the synthesized compounds are electrolytes so it is readily dissociated when poured into well and hence get into cell wall of bacteria and inhibit the replication of DNA, hence zone appeared. The proposed mechanism for antibacterial property of synthesized compounds is shown in the Figure 9. 


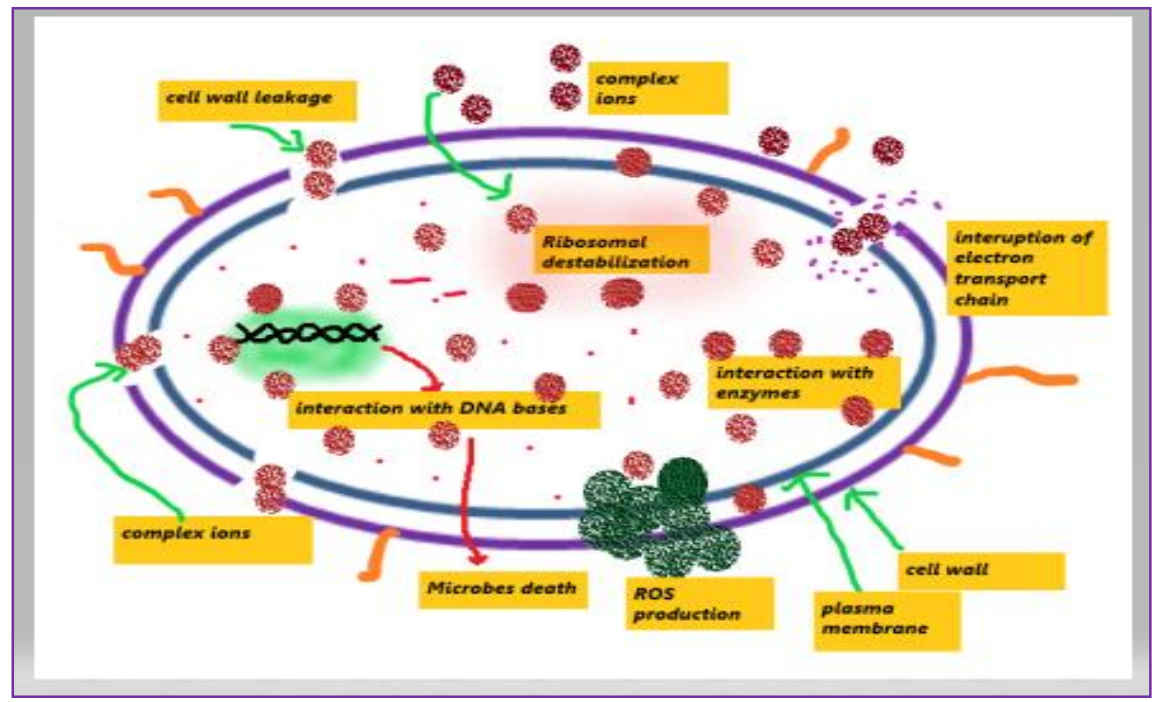

Figure 9. Proposed mechanism for Antibacterial activities

MIC for antibacterial and antifungal activities is given in Tables 8 and 9. Except the Schiff base ligand, all other complexes show minimum to maximum MIC values from $1.25 \mu \mathrm{g} / \mathrm{mL}$ to $5 \mu \mathrm{g} / \mathrm{mL}$. Overall, Complex 3 exhibits satisfactory results in antibacterial and antifungal study with highest zone of inhibition values $20 \mathrm{~mm}$ and $16 \mathrm{~mm}$ against Staphylococcus aureus and Aspergillus niger respectively.

\subsection{Antioxidant activity}

Antioxidant activities of the synthesized compounds are shown in the Table 10. Among the four different methods, the synthesized compounds showed better results in DPPH method (Figure 10). The powerful synergic antioxidant effect of the azido coordinated complexes may be due to donation of lone pair electrons from nitrogen to formation of stable free radical, so the production of free radical is reduced. The percentage of free radical scavenging activity was increased. The synthesized Schiff base complexes exhibit stronger antioxidant activity than the ligand $[27,28]$.

Table 10. Scavenging activity of the synthesized compounds

\begin{tabular}{|l|c|c|c|c|}
\hline \multirow{2}{*}{ Compound } & \multicolumn{4}{|c|}{ Scavenging activity $(3 \mu \mathrm{g} / 10 \mathrm{~mL})$} \\
\cline { 2 - 5 } & $\mathrm{DPPH}$ & $\mathrm{H}_{2} \mathrm{O}_{2}$ & CUPRAC & FRAP \\
\hline $\mathrm{L}^{1}$ & $5 \pm 0.9$ & $5 \pm 0.3$ & $10 \pm 0.6$ & $5 \pm 0.5$ \\
\hline Complex 1 & $58 \pm 1.5$ & $50 \pm 0.8$ & $35 \pm 1.8$ & $30 \pm 2.8$ \\
\hline Complex $\mathbf{2}$ & $55 \pm 0.8$ & $50 \pm 0.9$ & $45 \pm 2.8$ & $40 \pm 4.2$ \\
\hline Complex 3 & $68 \pm 1.5$ & $65 \pm 0.8$ & $45 \pm 2.8$ & $40 \pm 4.2$ \\
\hline Complex 4 & $65 \pm 5.5$ & $60 \pm 3.5$ & $50 \pm 1.5$ & $40 \pm 4.6$ \\
\hline
\end{tabular}




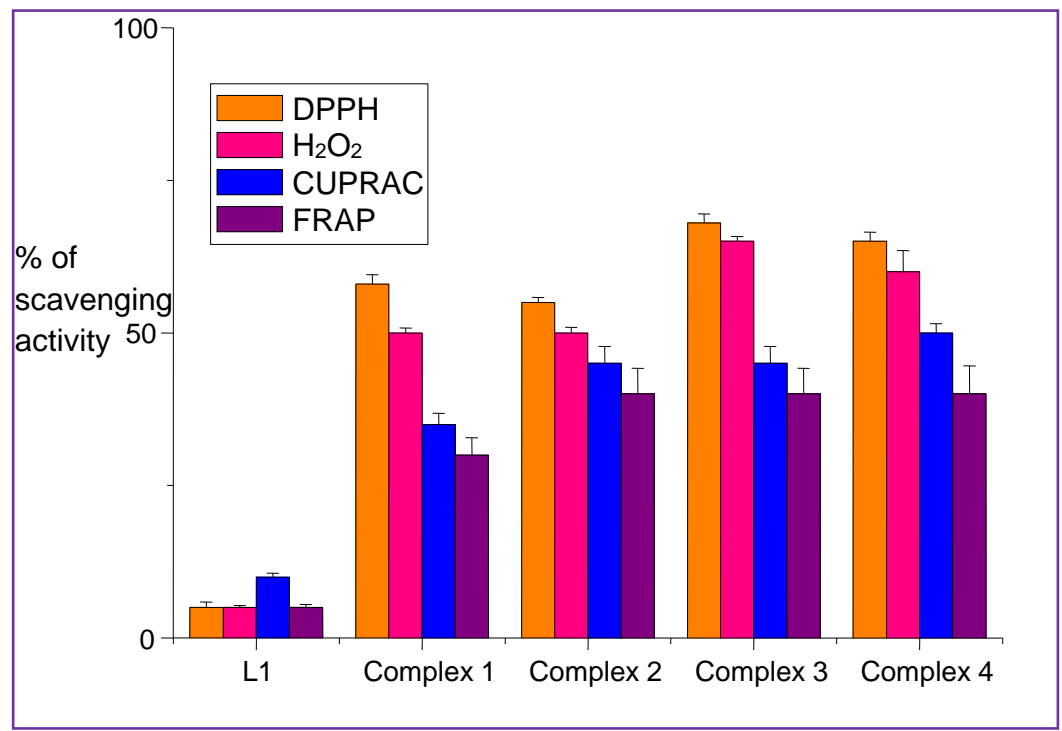

Figure 10. Graphical representation of the Scavenging activity

\section{Conclusion}

In the present study, Schiff base $\mathrm{Co}(\mathrm{II}), \mathrm{Ni}(\mathrm{II}), \mathrm{Cu}(\mathrm{II})$ and $\mathrm{Zn}$ (II) azido complexes were synthesized and characterized. A result of different physical and spectral analysis suggests tridendate nature of the synthesized Schiff base ligand. The structure of the Schiff base ligand was confirmed by ${ }^{1} \mathrm{H}$ NMR and ${ }^{13} \mathrm{C}$ NMR. The paramagnetic behavior of the Complex 3 was confirmed by EPR. The complexes possess effective larvicidal and ovicidal activities against C. quinquefasciatus. Antimicrobial activity against selected pathogenic microorganism produced good inhibition zones. Better results were obtained in MIC analysis. Radical scavenging activity of all the complexes exhibited good results. In particular, the synthesized Complex 3 showed highest ( $68 \%$ ) of the scavenging activity by DPPH method. Therefore, this study provides useful insight into the development of new route in medical field and also these complexes exhibits potent larvicidal properties.

\section{References:}

1. MusaratFarjana Yesmin, Sajjad Hossain, SaiyadNasira, Nayon Uddin Ashrafuzzaman, Masuqul Haque and Laila Arjuman Banu, "Cu (II) and Ni (II) Complexes of Schiff Base: Synthesis, Characterization and Antibacterial Activity”, Int. J. Adv. Res. Chem. Sci. vol. 7, no. 1, (2020), pp. 9-15.

2. V. K. Srivastava, "Synthesis, characterization and biological studies of some biometal complexes”, Futur J Pharm Sci. vol. 7, no. 51, (2021).

3. Imed-EddineBoulguemh, Adel Beghidja, Latifa Khattabi, Jerome Long and ChahrazedBeghidja, "Monomeric and dimeric copper(II) complexes based on bidentate N'-(propan-2-ylidende)thiophene carbohydrazide Schiff base ligand: Synthesis, structure, magnetic properties, antioxidant and anti-Alzheimer activities", Inorg. Chimi.Acta. (2020).

4. SakinehOmidi and Ali Kakanejadifard, "A review on biological activities of Schiff base, hydrazone and oxime derivatives of curcumin", Royal Society of Chemistry. vol. 50, (2020). 
5. Narendra Kumar Chaudhary, BiswashGuragain, Siyanand Kumar Chaudhary and Parashuram Mishra, "Schiff base metal complex as a potential therapeutic drug in medical science”, Bibechana. vol. 18, (2021), pp.214-230.

6. A. Koyuncu, A. Gonel and M. Durgun, "Assessment of the antiproliferative and apoptotic roles of sulfonamide carbonic anhydrase IX inhibitors in HeLa cancer cell line”, J Enzyme Inhib Med Chem. vol. 34, (2019), pp. 75-86.

7. L. John, R. S. Joseyphus and I. H, "Biomedical application studies of Schiff base metal complexes containing pyridine moiety: molecular docking and a DFT approach”, SN Appl. Sci. vol. 2, (2020), pp. 500.

8. X. Liu and J. R. Hamon, "Recent developments in penta, hexa and heptadentate Schiff base ligands and their metal complexes", Coord Chem Rev. vol. 389, (2019), pp. 94-118.

9. M. Farah Ibrahim and SaifaldeenAbdalhadi, "Performance of Schiff Bases Metal Complexes and their Ligand in Biological Activity: A Review”, Al-Nahrain Journal of Science. vol. 24, no. 1, (2021), pp. 1-10.

10. H. ZahidChohan, Asifa Munawar, T. Claudiu and Supuran, "Transition metal ion complexes of Schiff-bases. Synthesis, characterization and antibacterial properties”, Metal Based Drugs. vol. 8, no. 2, (2001).

11. S. JassimSultan, M. Sajed Lateaf and K. Dhuha, "Rashid Synthesis, Characterization and Antibacterial Activity of Mixed Ligand (HL) Complexes Mn(ll), Co(ll), Ni(ll), $\mathrm{Zn}(\mathrm{ll}), \mathrm{Cd}(\mathrm{ll})$ and $\mathrm{Hg}(\mathrm{ll})$ with Azide $\left(\mathrm{N}_{3}^{-}\right)$', Open Journal of Inorganic Chemistry. vol. 5, (2015), pp.102-111.

12. K. Lekaa, Abdul Karem, M. Israa, Radhi and S. Suhad, "Mohammed. Biological Activity of Complexes of Some Amino Acid: Review”, Indian Journal of Forensic medicine \& Toxicology. vol. 14, no. 4, (2020), pp. 2254-2261.

13. K. Robert Boggess and A. David Zatko, "The use of conductivity data for the structure determination of metal complexes", . Journal of Chemical Education. vol. 52, (1975), pp. 649-665.

14. S. B, Kalia, K. Lumba, G. Kaushal and M. Sharma, "Magnetic and structural studies on Cobalt(II) chelates of a dithiocarbazate derived from isoniazid", Int. J. Chem. Res. vol. 46 A, (2007), pp.1233-1239.

15. Waleed Mahmoud, M. Zainab Hassan, W. Russel and W. Ali, "Synthesis and spectral analysis of some metal complexes with mixed Schiff base ligands 1-[2-(2hydroxybenzylideneamino)ethyl]pyrrolidine-2,5-dione (HL1) and (2-hydroxybenzalidine) glycine (HL2)”, J. Phys.Conf. Ser. (2020).

16. K. Nakamoto, "Infrared and Raman Spectra of Inorganic and Coordination Compounds", $5^{\text {th }}$ Edition, Wiley-Interscience Publication. New York, 1978.

17. SundaramurthySantha Lakshmi, Kannappan Geetha and P. Mahadevi, "Tridentate Schiff base (ONO) transition complexes Synthesis, crystal structure, Spectroscopic and larvicidal studies", J. Chem. Sci. vol. 128, no. 7, (2016), pp. 1113-1118.

18. Chandan Adhikary, Dasarath Mal, Rupam Sen, Ashis Bhattacharjee, Philipp Gu"tlich, Siddhartha Chaudhuri and SubratanathKoner, "Synthesis, $X$-ray crystal structure and magnetic study of a novel 12-1,1-azido bridged dimeric copper(II) complex", Polyhedron. vol. 24, (2007), pp. 1658-1662. 
19. S. K. HafijurRahaman, Hoong-Kun Fun and Barindra Kumar Ghos, "A study on copper(II)-Schiff base-azide coordination complexes: Synthesis, $X$-ray structure and luminescence properties of $[\mathrm{Cu}(\mathrm{L})(\mathrm{N} 3)] \mathrm{X}\left(\mathrm{L}=\right.$ Schiff bases; $\left.\mathrm{X}=\mathrm{ClO}_{4}, \mathrm{PF} 6\right)$ ), Polyhedron. vol. 24, (2005), pp. 3091-3097.

20. J. Saranya and SundaramurthySantha Lakshmi, "In vitro antioxidant, antimicrobial and larvicidal studies of schiff base transition metal complexes", Journal of Chemical and Pharmaceutical Research, vol. 7, (2015), pp.180-186.

21. G. Y. Nagesh and B. H. M. Mruthyunjayaswamy, "Synthesis, characterization and biological relevance of some metal(II) complexes with oxygen, nitrogen and oxygen (ONO) donor Schiff base ligand derived from thiazole and 2-hydroxy-1naphthaldehyde”, Journal of Molecular Structure, vol. 1085, (2015), pp. 198-206.

22. Y. M. Issa, H. B. Hassib and H. E. Abdelaal, "'H NMR, ${ }^{13}$ C NMR and mass spectral studies of some Schiff bases derived from 3-amino-1,2,4-triazole”, Spectrochimica Acta Part A: Molecular and Biomolecular Spectroscopy. vol. 74, no. 4, (2009), pp. 902-910.

23. WHO and TDR, "Dengue Guidelines for Diagnosis, Treatment, Prevention and Control”, WHO Publications, Geneva, Switzerland, (2009).

24. A. Pereira Filho, G. C. D. Pessoa, L. F. Yamaguchi, M. A. Stanton, A. M. Serrav, R. H. M. Pereira, W. S. Neves and Kato M. J, "Larvicidal Activity of Essential Oils from Piper Species Against Strains of Aedes aegypti (Diptera:Culicidae) Resistant to Pyrethroids", Front. Plant Sci. vol. 12, (2021), pp. 685864.

25. National Committee for Clinical Laboratory Standards, Performance Standards for Antimicrobial Disk Susceptibility Tested Fifth Edition: Approved Standard M2-A5, NCCLS, Villanova, PA, USA, 1993a.

26. S. Syed Tajudeen and Geetha Kannappan, "Schiff Base Copper(II) Complexes: Synthesis, Spectral Studies and Anti-tubercular and Antimicrobial Activity", Indian Journal of Advances in Chemical Science. vol. 4, (2016), pp. 40-48.

27. Sayed Suliman Shah, Dawood Shah, Ibrahim Khan, Sajjad Ahmad, Umar Ali and Atiqur Rahman, "Synthesis and antioxidant activities of Schiff bases and their complexes: An updated review", Bio Interface Res Applied Chem. vol. 10, no. 6, (2020), pp. 6936-6963.

28. H. J. Dorman, A. Peltoketo, R. Hiltunen and M. J. Tikkanen, "Characterisation of the antioxidant properties ofde-odourised aqueous extracts from selected Lamiaceae herbs", Food Chem. vol. 83, (2003), pp. 255-262. 